\title{
口蓋裂患者の副鼻腔炎
}

\author{
石川 保之・川野 通夫*・本庄敢*
}

\section{Chronic Sinusitis in Patients with Cleft Palate}

\author{
Yasuyuki Ishikawa \\ (Nagahama Red Cross Hospital) \\ Michio Kawano and Iwao Honjo \\ (Kyoto University)
}

It has been reported that cleft palate patients often have sinusitis, but the details of their sinusitis are not known. We compared sinusitis in cleft palate patients with that in normal subjects, and we investigated the incidence of sinusitis in cleft palate patients in different age groups and the effect of medical treatment.

1) The incidence of sinusitis in cleft palate patients showed a peak at 3 to 5 years of age and then decreased gradually. After 12 to 14 years of age, the incidence of sinusitis remained constant at 36 to $39 \%$.

2) According to Nakosi's clinical classification of sinusitis, "restricted infection" was more frequent in cleft palate patients than in normal subjects.

3) Twenty six cleft palate patients with sinusitis were followed for more than 6 months. In the group of 15 treated conservatively, $11(73.3 \%)$ showed improvement. On the other hand, only two $(18.2 \%)$ of 11 untreated patients showed improvement.

Key words: cleft palate patients, sinusitis, treatment

\section{はじめに}

口蓋裂患者が副鼻腔炎を高率に伴うことは既 に報告されているが(1)2)，その原因や経過はな お明らかではない, 今回, 我々は, 口蓋裂患者 の副鼻腔炎の䍜患率 (年齢層別) 及び治療結果 を調べ，さらに，口蓋裂患者の副鼻腔炎と非口 蓋裂者のそれとの比較検討を行うことにより, 口蓋裂患者の副鼻腔炎の経過や原因について推 察を行った。

対象および方法

対象は口蓋裂患者 234 名, 年踰は 1 才から52
才, 平均 9.7 才, 性別は男性 132 名, 女性 102 名である. 裂型別症例数を表 1 亿示した. ま た，1986年 1 月から1987年 4 月の間に，本院耳 鼻咽喉科外来を受診し, 鼻内所見, 鼻レ線より 慢性副鼻腔炎と診断されたすべての非口蓋裂小 児 113 名（1〜14才）を対照とした.さらに， 非口蓋裂者の副鼻腔炎の権患率を調查するた め, 6 才から14才の小児1625名, 16才から69才 の成人 306 名に抢いて検晾（前鼻鏡検査）を行 った。

方法は以下の項目について各方法により調査 
した.

1）口蓋裂患者と非口蓋裂者の副鼻腔炎の罹 患率

口蓋裂患者で，前鼻鏡検査を行ったあと，必 要により鼻のレントゲン撮影を行い, 副鼻腔炎 の罹患率を年齢層別に調べた。なお，レ線所見 の判定は1965年の文部省綜合研究班の規準によ った ${ }^{3)}$. 非口蓋裂者の副鼻腔炎の罹患率は検診 （前鼻鏡検査）により調べ，口蓋裂患者の対照 とした.

2 ）口蓋裂患者の副鼻腔炎の特徵（臨床病型 及び病変程度について)

口蓋裂小児副鼻腔炎例73名, 非口蓋裂小児副 鼻腔炎例 113 名を名越 ${ }^{45) 6)}$ による副鼻腔炎の臨 床病型分類に従って分類し, 両群の比較を行っ た。また，鼻レ線で，両側の穊骨洞，上顎洞の うち，最も強い陰影を示した洞が $(+)( \pm)$ の場合を軽度, (H) の場合を中等度, (H) の 場合を高度の副鼻腔炎として分類し, 両群の比 較を行った。

3）口蓋裂患者の副鼻腔炎の治療経過 副鼻腔炎を有する口盖裂患者において，6 ケ
月以上経過観察のできた 26 名（ 5 才〜 15 才）で 改善率を調べた. 改善度の判定基準は表 2 の如 くである。まず，各洞のレ線所見で（一）を 0 ，（土）を0.5，（十）を $1,(H) を 2,(H)$ を 3 とスコア化し, 両側の上顎洞, 穊骨洞のス コア合計を算出した。 そして, 初診㭙のスコア 合計を $100 \%$ とし，6 ケ月以上後の診察時のス コア合計を百分率であらわし，スコア合計が 20 \%以下に減少したものを著明改善，20〜 50\%に 減少したものを改善，50〜80\%に減少したもの をやや改善，80\%以上にとどまったものを不変 あるいは悪化とした。

表 1 裂型別症例数

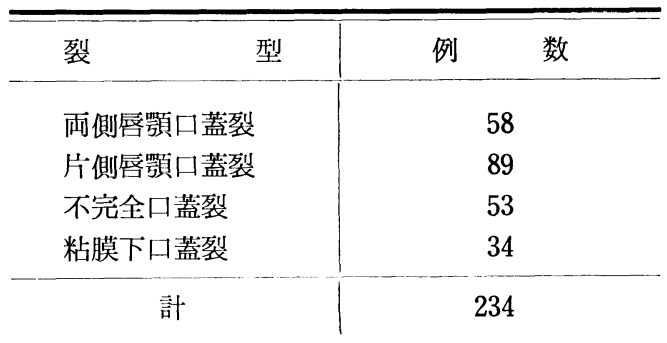

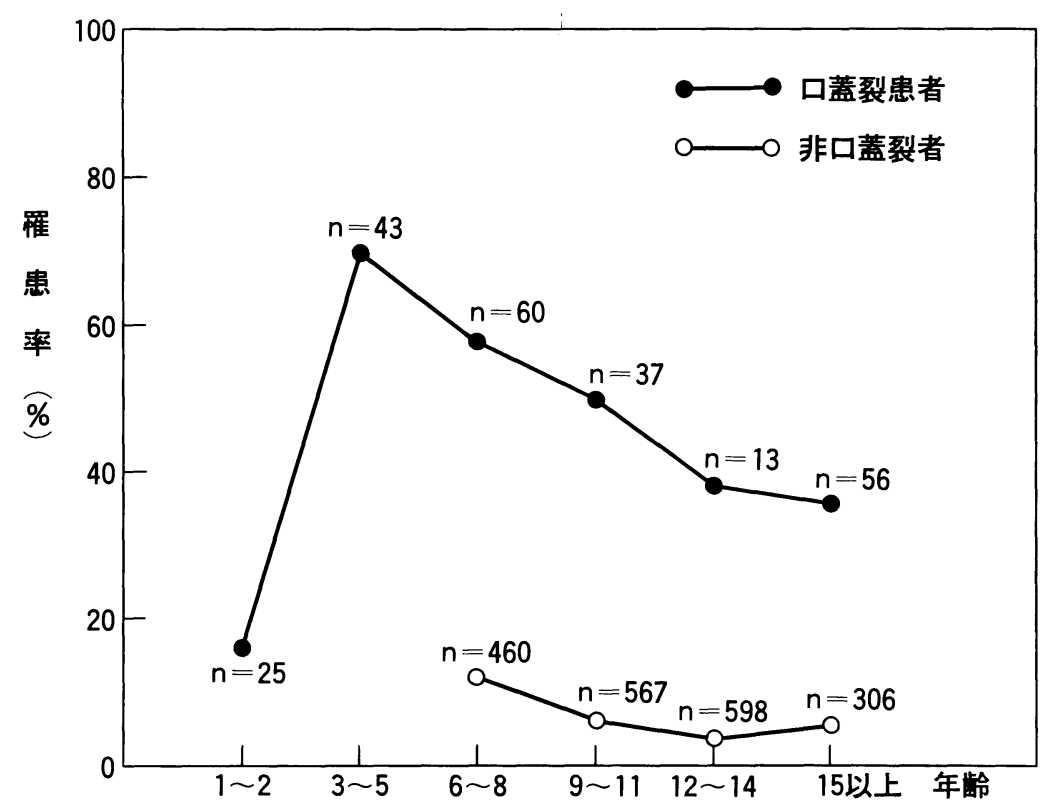

図 1 口蓋裂患者及び非口蓋裂者の副鼻腔炎悗患率 


\section{結果}

1 ）口蓋裂患者と非口蓋裂者の副鼻腔炎の䨀 患率

図 1 の如く, 口蓋裂患者の副鼻腔炎の曜患率 は, 1 方で $16.0 \%, 3 \sim 5$ 才で $69.8 \%, 6$ 〜 8才で $58.3 \%, 9 \sim 11$ 才で $51.4 \%, 12$ 14才 で38.5\%，15才以上で35.7\%を示し，3〜 5 才 で最む高率であり，その後は加齢とともに低下 し，12〜14才以後は36〜39\%とほぼ一定の罪患 率を示した。一方, 非口蓋裂者の罹患率は 6 〜 8 才で $12.6 \%, 9$ 〜1才で $6.5 \%, 12$ 14才で $4.0 \%, 16$ 才以上で $6.2 \%$ で, どの年齢層でも口

表 2 改善の判定基準（レ線による）

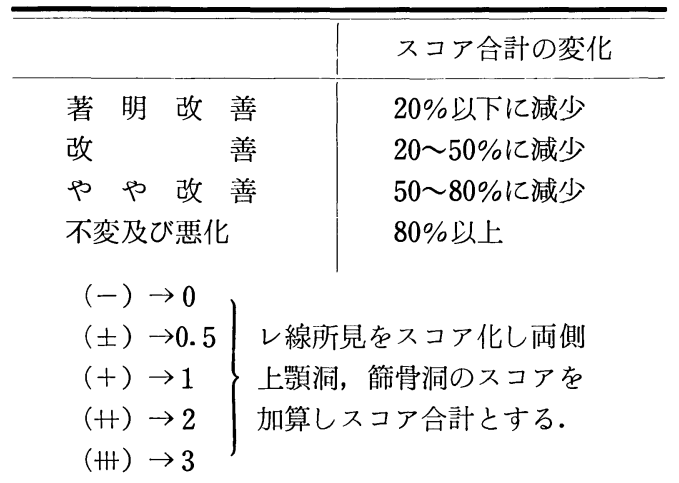

表 3 非口蓋裂児と口蓋裂児の副鼾腔炎の 臨床病型分類 (1～8才)

\begin{tabular}{l|r|r}
\hline \multicolumn{1}{c|}{ 病 型 } & 非口蓋裂児 & \multicolumn{1}{|c}{ 口蓋裂児 } \\
\hline 限局感染型 & $13(14.9 \%)$ & $28(50.9 \%)$ \\
ビマンカタル型 & $71(81.6 \%)$ & $24(43.7 \%)$ \\
浮腫茸状型 & $3(3.5 \%)$ & $3(5.4 \%)$ \\
\hline \multicolumn{1}{c|}{ 計 } & $87(100 \%)$ & $55(100 \%)$
\end{tabular}

表 4 非口蓋裂児と口蓋裂児の副鼻腔炎の 臨床病型分類（9１4才）

\begin{tabular}{c|r|r}
\hline \hline 病 型 & 非口蓋裂児 & 口蓋裂児 \\
\hline 限局感染型 & $6(23.0 \%)$ & $8(44.4 \%)$ \\
ビマンカタル型 & $19(73.1 \%)$ & $10(55.6 \%)$ \\
浮腫茸状型 & $1(3.9 \%)$ & $0(0 \%)$ \\
\hline 計 & $26(100 \%)$ & $18(100 \%)$
\end{tabular}

蓋裂患者より著しく低かった。

2 ）口盍裂患者の副鼻腔炎の特徵（臨床病型 及び病変程度について)

表 3，4 は口蓋裂小児副鼻腔炎例73名（1～ 8 才， 55 名，9１4才，18名，非口蓋裂小児 副鼻腔炎例 113 名（1８才，87名，9〜14 才, 26名）を臨休病型により分類したものであ る. 表の如く，1〜8才では口盖裂小児は非口 蓋裂小児に比して限局感染型が有意に多いこと がわかった，9〜14才でも，有意差ではないが 同様の傾向を認めた.

表 5, 6 は鼻レ線による副鼻腔炎の重症度分 類である. 表の如く, $1 \sim 8$ 才では口蓋裂小児

表 5 非口蓋裂児と口蓋裂児の副鼻腔炎の 病変程度 $(1 \sim 8$ 才 $)$

\begin{tabular}{|c|c|c|c|}
\hline 程 & 度 & 非口蓋裂児 & 口蓋裂児 \\
\hline 高 & 度 & $2(2.3 \%)$ & $0\left(\begin{array}{ll}0 & \%\end{array}\right)$ \\
\hline 中 等 & 度 & $45(51.7 \%)$ & $12(21.8 \%)$ \\
\hline 軽 & 度 & $40(46.0 \%)$ & $43(78.2 \%)$ \\
\hline 計 & & $87(100 \%)$ & $55(100 \%)$ \\
\hline
\end{tabular}

表 6 非口蓋裂児と口蓋裂児の副鼻腔炎の 病変程度 $(9 \sim 14$ 才 $)$

\begin{tabular}{|c|c|c|c|}
\hline 程 & 度 & 非口荎裂児 & 口蓋裂児 \\
\hline 高 & 度 & $0\left(\begin{array}{ll}0 & \%\end{array}\right)$ & $0\left(\begin{array}{ll}0 & \%\end{array}\right)$ \\
\hline 中 等 & 度 & $13(50 \%)$ & $7(38.9 \%)$ \\
\hline 軽 & 度 & $13(50 \%)$ & $11(61.1 \%)$ \\
\hline 計 & & $26(100 \%)$ & $18(100 \%)$ \\
\hline
\end{tabular}

表 7 治療の有無による改善率（小児例）

\begin{tabular}{|c|c|c|}
\hline 改 善 度 & 治療(t) & 治療(一) \\
\hline 著眀改善 & $3)$ & 0 \\
\hline 改 善 & $6\} 73.3 \%$ & $1\} 18.2 \%$ \\
\hline やや改善 & & $1)$ \\
\hline 不変及び覀化 & 4 & 9 \\
\hline 計 & 15 & 11 \\
\hline
\end{tabular}


は非口蓋裂小児に比して軽度の副鼻腔炎が有意 に多いことが明らかとなった，9１4才では有 意差は認めないが，同様の傾向を認めた。

なお，成人については，口蓋裂患者の副鼻腔 炎の例数が十分でなかったので非口蓋裂者との 比較は出来なかった。

3 ）口蓋裂患者の副鼻腔炎の治療経過

6 ケ月以上経過钼察のできた 26 例のうち，治 療例は15例, 無治療例は11例であった。表 7 の 如く, 治療例では $73.3 \%$, 無治療の屯のでは 18.2\%の改善率であった。乙れら治療例の治療 方法は, 鼻処置, ネブライザー, 内服を主体と するものであった。

\section{考按}

非口蓋裂小児での副鼻腔炎の頻度は，深口 $(1981)^{7)}$ は $5 \%$ 以下，島田 $(1980)^{8)}$ は約 $10 \%$ と報告しており，我々の結果むほぼ一致した。 ところが，口蓋裂患者は著しく高い罹患率を示 し, 年秢別頻度は $3 \sim 5$ 才が最む高く, この年 秢で発症するものが多いものと思われた。 ま た，12〜14才頃に減少傾向があらわれ，以後は ほぼ一定の罹患率を示した。乙れら口蓋裂患者 は初彰時ほとんどの者が治療歴をもっていなか った，非口蓋裂小児の副鼻腔炎について，梅 沢9) は，発育成長過程で約 $60 \%$ が治癒・軽快を 示し，10１4才で治瘾傾向があらわれると述へ ている。 また，高坂 ${ }^{10)}$ は，非口蓋裂小児の副鼻 腔炎罹患のピークは小学校低学年かそれ以前の 幼稚園児位にあって, 学年が進むにつれて自然 治癒傾向を示すと述べており，口蓋裂例での副 鼻腔炎の罹患率の推移は非口蓋裂小児の場合之 類似している， 口蓋裂患者の副鼻腔炎の経過に おいても，年跲的要因があるものと思われた。

しかし，どの年齢層に执いても口蓋裂患者は非 口蓋裂者より著しく高い羅患率を示していた。

非口蓋裂小児の副鼻腔炎の臨床病型分類（名 越による）については次のような報告がみられ た。荒李 ${ }^{6)}$ は小坚副鼻腔炎 180 例のうち，限局 感染型 $9 \%$, ビマンカタル型 $86 \%$, 浮腫茸状型 $5 \%$ あったと述へ，名越 5 は 158 例のうち限
局感染型 $21.5 \%$, ビマンカタル型 $74.7 \%$, 浮腫 茸状型 $3.8 \%$ と報告しており, ビマンカタル型 が多数を占めているてとがわかる. 今回の我々 の調査であ非口蓋裂小児ではビマンカタル型が 多数を占め, 上記の報告と同椂であった。一 オ，口蓋裂小児の副鼻腔炎では，限局感染型が 多いてとがわかった。 また, 病変程度について も，口蓋裂小児では軽度の副鼻腔炎が多いこと が示された。名越 ${ }^{11}$, 梅沢 ${ }^{9)}$ は, ビマンカタル 型は小照期の体質的特徽を采因として発症した あのであり, 限局感染型の発症には局所的素因 が強く関与していると述べている. 以上のてと より, 口盖裂小尘の副鼻腔炎の発症には, 局所 的因子が強く関与しているものと推测される. また，口蓋裂小児の副鼻腔炎は非口蓋裂小皆の それに比して病変程度の柽度のもが多いという 倾问も持つが，乙れも局所的因子が発症の基盤 になっていることと無関係ではないむのと思わ れた。 この局所的因子として, 裂の存在, 上顎 洞の発育不全, 鼻中隔弯曲, 鼻咽腔閉鎖不全, 粘液線毛機能障害等が考えられる。我々は, 口 蓋裂患者の副鼻腔炎の頻度は裂型, 裂侧, 鼻中 隔弯曲之関係がないととを報告したが, 今後, 鼻咽腔閉鎖不全や粘液線毛機能障害など検討す る予定である。

口蓋裂患者の副鼻腔炎の治療成績に関する報 告は，我々の検索した範囲ではまだ見あたらな い. 今回の結果では, 治療による改善が十分に 期待できるものと思われ，乙の理由として，口 蓋裂患者の副鼻腔炎は局所的要因が強いとと及 び軽度であることがあげられる、今後, 口蓋裂 児の定期検診を確実に行い, 副鼻腔炎の治療を 積極的に行うことにより，さらに罹患率を下げ ることが可能であると考えられた。

\section{まとめ}

1 ）口蓋裂患者の副鼻腔炎の罹患率は $3 \sim 5$ 才でピークを示し, 以後, 加榆とともに低下 し，12〜14才以後は36〜39\%とほぼ一定の罹患 率を示した。

2) 副鼻腔炎を臨床病型分類に従ってみる 
と，非口蓋裂小児ではビマンカタル型が多数を 占めるのに比して，口蓋裂小児では限局感染型 が多く,また, 病変程度の軽いものが多かっ た.

3 ）口蓋裂小児の副鼻腔炎例で 6 ケ月以上観 察のできた 26 例をみると, 治療例では 15 例中 11 例が, 無治療例では11例中 2 例が改善を示し, 治療効果が認められた。

\section{参考文献}

1 ）三苫藤吉郎，他：口蓋裂例の鼻副鼻腔疾患. 日本 鼻科学会会誌 $23: 159 \sim 160,1984$.

2 ) 石川保之, 他：口蓋裂と鼻副鼻腔疾患. 日口蓋誌 II : 199 205, 1986.

3 ）熊澤忠躬，野村恭也：鼻科学臨床所見の定量化. 163頁, 金原出版, 東京, 1985.

4 ) 名越好古：小児慢性副鼻腔炎の臨床. 耳展 3： 補 $3 ; 293 \sim 299,1960$.
5 ）名越好古, 他：慢性副鼻腔炎の自然変動に対する 発言. 耳展 9 : 補 $4 ； 402 \sim 407,1966$.

6 ）荒木昭夫, 川城信子：小児副鼻腔炎の追跡調査. 耳喉 $59: 261 \sim 266,1987$.

7 ）浜口幸吉, 他：当教室における 8 年間の学校検診 の統計学的検討. 耳鼻臨床 $74:: 1072 \sim 1080$, 1981.

8 ）島田和哉: 学童検診よりみた小児副鼻腔炎の変 遷. 耳喉 $52: 545 \sim 552,1980$.

9 ）梅沢美和子：小児期鼻副鼻腔炎の予後に関する研 究. 耳展 $17:$ 補 $1 ; 5 \sim 23,1974$.

10）高坂知節，他：小児鼻副鼻腔炎病態の現状一学童 検診結果より一. 日耳鼻 $84: 628 \sim 636,1981$.

11）名越好古：小児副鼻腔炎の変遷と対策. 耳喉 52 : 539〜 544, 1980.

原稿採択：昭和62年 8 月 25 日 別刷請求先 : 石川保之

于526 長浜市宮前町14-7 長浜赤十字病院耳鼻咽喉科 